\title{
PERSENTASE BIAYA BAHAN BAKU, BIAYA TENAGA KERJA, BIAYA OVERHEAD PABRIK TERHADAP HARGA POKOK PRODUKSI PADA PT. MAJU TAMBAK SUMUR
}

\author{
Oleh: Yusni Arni \\ (UNIVERSITAS MEGOUPAK TULANGBAWANG LAMPUNG)
}

yusniarniyusuf@,gmil.com

\begin{abstract}
Abstrak-Penelitian ini bertujuan untuk mengetahui (1) persentase biaya bahan baku, terhadap harga pokok produksi pada PT. Maju Tambak Sumur (2) persentase Biaya tenaga kerja terhadap harga pokok produksi pada PT. Maju Tambak Sumur(3) persentase biaya overhead pabrik terhadap harga pokok produksi pada PT. Maju Tambak Sumur dan (4) Seberapa besar jumlah rasio (persentase) biaya bersama terhadap harga pokok produksi pada PT. Maju Tambak Sumur. Penelitian ini dilaksanakan pada PT. Maju Tambak Sumur, Way urang kalinda lampung Selatan Data dikumpulkan dengan metode wawancara dan dokumntasi. Dan selanjutnya dianalisis dengan analisis deskriptif. Hasil penelitian menunjukan bahwa Pada PT. Maju Tambak Sumur Besar biaya bahan baku memberikan persentasenya terhadap harga pokok produksi selama tahun 2014 sebesar 41,09\%. (2) Biaya tenaga kerja pada PT. Maju Tambak Sumur terlihat persentasenya sebesar 14,50\%. (3) Biaya Overhead Pabrik pada PT. maju Tambak Sumur memberikan persentase terhadap harga pokok produksi sebesar 44,41\%. Dan (4) Jumlah rasio (persentase) biaya bersama terhadap harga pokok produksipada PT. Maju Tambak Sumur sebesar 13,30\%.
\end{abstract}

Kata Kunci: Biaya Bahan Baku, Biaya Tenaga Kerja, Biaya Overhead

\begin{abstract}
This study aims to determine (1) the percentage of raw material cost on the cost of production in PT. Maju Tambak Sumur, (2) the percentage of labor costs on the cost of production in PT. maju tambak Sumur, (3) the percentage of factory overhead cost in PT. Maju Tambak Sumur. The research was conducted in the village PT.Maju Tambak Sumur,Way Urang Kalianda. Data were collected by interview and documentation. And then analyzed with descriptive analysis. The results showed that the great in PT. Maju Tambak Sumur raw material costs give a percentage of the cost, of production for 2014 amounted to 41,09\%, (2) labor costs in PT. Maju Tambak Sumurgives the percentage for 14,50\%, (3) the factory overhead costs on PT. maju Tambak Sumur give the percentage of yhe cost, of production of 44,41\%. The amound of the cost rasio the costs of production in PT. Maju Tambak Sumur give the percentage of yhe cost 13,30\%.
\end{abstract}

Keywords: Material Cost, Labor Costs, Overhead Cost

PENDAHULUAN

Perusahaan merupakan suatu organisasi yang mempunyai kegiatan tertentu yang sangat kompleks. Pertumbuhan suatu badan usaha biasanya tidak lepas dari 
permasalahan yang dihadapi perusahaan.Hal ini dapat terlihat dari banyaknya transaksi yang terjadi, perubahan dan permintaan konsumen dan target yang diinginkan pemilik modal.Permasalahan tersebut diiringi dengan adanya situasi dan kondisi yang semakin kompetitif.Maka para pengusaha dan manager memperoleh tantangan yang lebih berat yaitu meningkatkan efektifitas serta efesiensi operasi perusahaan yang dikelola. Peningkatan efektifitas dan efesiensi tersebut tidak lepas dari bagaimana menejemen perusahaan dapat merencanakan, mengorganisasikan dan mengawasi jalannya perusahaan. Jadi, untuk mencapai tujuan tersebut perusahaan memerlukan suatu menejemen dalam mengelola factor produksi. Sehingga sumber-sumber yang ada didalam maupun diluar perusahaan dapat dikelola sedemikian rupa untuk memperoleh hasil dan daya guna yang maksimal.

Dalam perusahaan barang maupun jasa tentunya menginginkan usahanya semakin lama semakin berkembang sesuai dengan tujuan yang ingin di capai, baik itu tujuan jangka pendek maupun tujuan jangka panjang.Secara umum tujuan dari dari setiap perusahaan adalah memperoleh laba dari hasil penjualan produk yang dihasilkan. Dalam penjualan produk, penetapan harga jual produk tentunya akan menentukan besarnya laba yang akan diperoleh perusahaan. Besar kecilnya penentuan harga jual suatu produk akan dilihat dari berapa besar biaya poduksi yang dikeluarkan. Perusahaan yang mempunyai kualitas produk yang unggul dengan harga yang bersaing dibandingkan dengan perusahaan lain yang sejenis, tentu akan sangat membantu dalam persaingan yang sangat begitu ketat. Dalam persaingan harga, merupakan factor internal yang dapat dikuasai sepenuhnya oleh perusahaan.Maka itu perusahaan berusaha untuk menetapkan biaya produksi tersebut dengan cermat agar menghasilkan harga pokok - produk yang tepat.

Biaya produksi merupakan biaya yang digunakan untuk menghasilkan produk dalam suatu perusahaan yang dapat ditentukan secara kuantitatif. Dalam perusahaan industri, masalah biaya pokok produksi merupakan hal yang sangat penting diperhatikan, karena kesalahan dalam menentukan biaya pokok produksi akan membawa pengaruh tidak baik terhadap kontinuitas usaha dan menyebabkan kegagalan bagi perusahaan yang bersangkutan. Komponen biaya produksi terdiri dari biaya bahan baku langsung, biaya tenaga kerja langsung dan biaya overhead pabrik Mursyidi (2008 : 221). Yang termasuk dalam biaya produksi langsung yaitu bahan baku langsung dan biaya tenaga kerja langsung. Sedangkan biaya produksi tidak langsung adalah biaya overhead pabrik atau yang sering disebut 
sebagai biaya fabrikasi (factory overheadcost). Biaya overhead pabrik yaitu biayaproduksi selain biaya bahan baku dan biaya tenaga kerja langsung. Komponen biaya overhead pabrik yaitu biaya bahan baku tidak langsung dan biaya tenaga kerja tidak langsung. Selain kedua biaya overhead pabrik tersebut juga terdapat biaya overhead pabrik lainnya seperti: biaya pemeliharaan, biaya penyusutan, biaya pembangkit listrik dan lain sebagainya.

Pada perusahaan PT. maju Tambak Sumur biaya - biaya yang dibebankan oleh perusahaan dalam menghitung biaya pokok produksinya meliputi biaya bahan baku, biaya tenaga kerja, dan biaya over head sudah di perhitungkan sebagai mana mestinya dalam penghitungan biaya pokok produksi. Namun dalam penghitungan biaya pokok produksinya, perusahaan belum membebankan biaya - biaya secara keseluruhan. Biaya yang paling mempengaruhi dari biaya biaya yang ada adalah biaya tenaga kerja karena pada saat perusahaan melakukan proses produksi dengan jumlah kecil, jumlah tenaga kerja yang bekerja sangat banyak sehingga perusahaan harus menyesuaikan besarnya jumlah produksi dengan biaya -biaya untuk tenaga kerja. Selain itu dalam penentuan harga pokok penjualan perusahaan mengalami hambatan pada saat dihadapkan oleh harga bahan baku yang terlalu tinggi, sehingga perusahaan harus mencari pedagang ikan yang mau menjual ikan tersebut dengan harga yang lebih murah agar proses produksi dapat terus berjalan. Biaya-biaya yang belum terkalkulasi dalam perhitungan biaya pokok produksi terjadi pada komponen biaya tenaga kerja langsung, yaitu biaya jaminan social tenaga kerja.Berdasarkan uraian diatas mengingat pentingnya penentuan biaya pokok produksi, maka dipandang perlu untuk melakukan penelitian pada perusahaan PT. Maju Tambak sumur dalam hal penentuan biaya pokok produksi.

Adapun permasalah yang ingin dikaji dalam penelitian ini adalah pertama seberapa besar persentase biaya bahan baku, terhadap harga pokok produksi pada PT. Maju Tambak Sumur tahun 2014. Kedua, seberapa besar persentase biaya tenaga kerja, terhadap harga pokok produksi pada PT. maju Tambak Sumur tahun 2014.Ketiga, seberapa besar persentase biaya overhead pabrik, terhadap harga pokok produksi pada PT. Maju Tambak sumur tahun 2014.

Dalam rangka menjawab permasalahan tersebut, maka penelitian ini bertujuan untuk pertama, mengetahui besarnya persentase biaya bahan baku, terhadap harga pokok produksi pada PT. Maju Tambak Sumur tahun 2014. Kedua, mengetahui persentase biaya tenaga kerja terhadap harga pokok produksi pada PT. Maju 
Tambak sumur tahun 2014.Ketiga, mengetahui persentase biaya overhead pabrik terhadap harga pokok produksi pada PT. Maju Tambak sumur tahun 2014.

Manfaat penelitian ini adalah secara teoritis hasil penelitian ini diharapkan dapat menemukan proposisi yang bisa di uji guna menambah wawasan atau pengetahuan khususnya dalam biaya bahan baku, biaya tnaga kerja, dan biaya overhead pabrik yang memberikan pengaruh terhadap harga pokok produksi. Secar praktis bagi perusahaan penelitian ini diharapkan dapat memberikan sumbangan pemikiran kepada pihak peruahaan, khususnya dalam memperhatikan biaya bahan baku, biaya tenaga kerja, dan biaya overhead pabrik terhadap harga pokok produksi serta memberikan informasi tambahan dan dapat dijadikan masukan bagi pengembangan ilmu pengetahuan yang berkaitan dengan produksi dan ketenagakerjaan serta berguna bagi perkembangan industri pengalengan ikan di Bandar Lampung. Bagi Universitas Megou Pak Tulang Bawang lampung penelitian ini diharapkan bisa menjadi salah satu bahan bacaan ilmiah di perpustakaan yang bisa di manfaatkan oleh anggota perpustakaan yang memerlukan referensi dalam melakukan penelitian yang sejenis.

\section{METODE}

Metode penelitian ini termasuk penelitian deskriptif dengan pendekatan kuantitatif.Penelitian deskriptif kuantitatif adalah penelitian yang menggambarkan status sekelompok manusia, suatu objek, suatu kondisi, suatu pemikiran, ataupun suatu kelas peristiwa pada masa sekarang disertai dengan angka-angka dan grafik (Moh. Nasir, 2011:54). Teknik pengumpulan data yang digunakan dalam penelitian ini adalah teknik wawancara yaitu digunakan untuk mengetahui jalannya proses produksi, serta menganalisis laporan harga pokok produksi untuk melihat seluruh biaya produksi yang digunakan, serta teknik dokumentasi digunakan untuk mengumpulkan data mengenai rincian biaya produksi pada PT. Maju Tambak Sumur. Sumber data yang digunakan adalah data sekunder, sedangkan jenis data yang digunakan dalam penelitian ini adalah jenis data kuantitatif.Teknik pengumpulan data yang digunakan adalah wawancara (interview) dan dokumentasi.Teknik analisis data yang digunakan dalam penelitian ini adalah analisis deskriptif kuantitatif.

\section{HASIL DAN PEMBAHASAN}

1) Persentase Biaya bahan baku, terhadap harga pokok produksi pada PT. Maju Tambak sumur Tahun 2014.

Perusahaan ini merupakan perusahaan yang bergerak dalam 
bidang industri.Dimana perusahaan ini merupakan perusahaan pengalengan ikan. Dalam proses produksinya perusahaan belum melakukan penghitungan untuk melihat seberapa besar biaya yang dikeluarkan perusahaan diantaranya biaya bahan baku, biaya tenaga kerja, dan biaya overhead pabrik. Dari ke tiga jenis biaya - biaya produksi yang dikeluarkan oleh perusahaan pada PT.Maju Tambak Sumur semua memberikan kontribusi terhadap harga pokok produksi dan semuanya memberikan persentase yang berbeda dalam harga pokok produksi. Biaya bahan baku, biaya tenaga kerja, dan biaya overhead pabrik merupakan salah satu biaya paling berpengaruh dalam melihat harga pokok produksi karena dengan adanya biaya tersebut perusahaan dapat mengetahui besarnya biaya yang dikeluarkan perusahaan selama proses produksi dalam kurun waktu tertentu. Sebelum melakukan penghitungan untuk melihat besarnya persentase terlebih dahulu untuk melakukan penghitungan untuk melihar besaran biaya - biaya yang dikeluarkan oleh perusahaan.Persentase Biaya Bahan Baku terhadap Harga Pokok Produksi dapat dihitung sebagai berikut.

$$
=\frac{\text { biaya bahan baku }}{\text { jumlah hpp }} \times 100 \%=\ldots \%
$$

Sehingga diperoleh persentase biaya bahan baku terhadap Harga Pokok Produksi sebagai berikut:

Tabel 1. Presentase biaya bahan baku pada tahun 2014

\begin{tabular}{|c|c|c|c|}
\hline Bulan (1) & Biaya Bahan Baku (2) & \multicolumn{2}{|c|}{ Jumlah Hpp (3) \% (2):(3)×100\%) } \\
\hline Januari & 2.510 .519 .395 & 6.394 .710 .386 & 39,25 \\
\hline Februari & 2.250 .464 .605 & 5.441 .078 .848 & 41,36 \\
\hline Meret & 2.319 .011 .631 & 5.477 .527 .495 & 42,34 \\
\hline April & 2.625 .560 .771 & 6.747 .400 .881 & 38,91 \\
\hline Mei & 2.742 .843 .429 & 6.939 .784 .639 & 39,52 \\
\hline Juni & 2.326 .987 .275 & 5.879 .599 .183 & 46,65 \\
\hline Juli & 2.035 .177 .984 & 4.804 .475 .329 & 42,36 \\
\hline Agustus & 2.452 .858 .812 & 5.652 .613 .972 & 43,39 \\
\hline Srptember & 2.374 .595 .342 & 5.561 .610 .577 & 42,69 \\
\hline Oktober & 4.207 .074 .631 & 9.482 .964 .553 & 44,36 \\
\hline November & 2.911 .107 .496 & 7.326 .050 .611 & 39,74 \\
\hline Desember & 2.691 .589 .527 & 6.653 .822 .780 & 40,45 \\
\hline Jumlah & 31.447 .790 .898 & 76.517 .511 .254 & 41,09 \\
\hline
\end{tabular}

(Sumber : Lampiran 3) 
Dapat diketahui seberapa besar biaya bahan baku memberikan persentasenya terhadap harga pokok produksi pada perusahaan selama tahun 2014. Adapun besarnya persentase biaya bahan baku terhadap harga pokok produksi selama tahun 2014 dapat dijelaskan sebagai beriku. Pada Bulan Januari persentase Biaya Bahan Baku terhadap Harga Pokok Produksi sebesar 39,25\%, sementara pada bulan februari terjadi peningkatan persentase biaya bahan baku terhadap harga pokok produksi menjadi $41,36 \%$, selanjutnya untuk bulan maret biaya bahan baku mengalami peningkatan kembali dengan memberikan persentase sebesar42,34\% terhadap harga pokok produksi,Kemudian pada Bulan April biaya bahan baku mengalami penurunan dengan memberikan persentase sebesar 38,91\% terhadap harga pokok produksi. Selanjutnya pada Bulan Mei biaya bahan baku memberikan persentase sebesar 39,52\% terhadap Harga Pokok Produksi.Selanjutnya pada bulan Juni biaya bahanbaku mengalami peningkatan dengan memberikan persentase sebesar $46,65 \%$ terhadap Harga Pokok Produksi. Selanjutnya pada Bulan Juli biaya bahan baku memberikan persentase sebesar 42,36\% terhadap Harga Pokok Produksi. Kemudian pada Bulan Agustus biaya bahan baku memberikan persentase sebesar
43,39\% terhadap Harga Pokok Produksi.

Sementara pada Bulan September biaya bahan baku memberikan persentase sebesar $42,69 \%$ terhadap harga pokok produksi. Kemudian pada Bulan Oktober biaya bahan memberikan persentase sebesar $44,36 \%$ terhadap harga pokok produksi. Kemudian Bulan November biaya bahan baku memberikan persentase sebesar $39,74 \%$ terhadap harga pokok produksi.Sementara pada Bulan Desember biaya bahan memberikan persentase sebesar $40,45 \%$ terhadap harga pokok produksi.

Pada kondisi tersebut dapat diketahui besarnya persentase yang masuk terhadap harga pokok produksi melalui perhitungan yang menggunakan analisis tersebut berfungsi terhadap perusahaan sehingga dapat mengetahui besarnya persentase biaya bahan baku selama kurun waktu tertentu.

2) Perhitungan Persentase Biaya Tenaga Kerja terhadap harga pokok produksi.

Perhitungan untuk melihat persentase biaya tenaga kerja terhadap harga pokok produksi digunakan untuk melihat seberapa persentasebesar biaya tenaga kerja tersebut memberikan persentasenya terhadap harga pokok produksi,sehingga perusahaan dapat memperhitungkan biaya tenaga kerja dalam periode tertentu. Biaya tenaga 
kerja merupakan elemen biaya produksi yang cukup besar sehingga amat penting perlu dilakukan pengawasan terhadap biaya tenaga kerja, tujuannnyauntuk mencapai efesiensi tenaga kerja, termasuk didalamnya penentuan tingkat kompensasi yang memadai,menjaga agar kualitas memenuhi standart kualitas, dan dapat dicapainya volume produksi secara optimal.Perhitungan dapat dilakukan dengan menggunakan rumus sebagai berikut.

$\frac{\text { biaya tenaga kerja }}{\text { jumlah hpp }} \times 100 \%=$

Berdasarkan hasil analisis yang dilakukan, maka didapatkan hasil yang akan dipaparkan dalam tabel 4.3 berikut ini.

Tabel 2. Persentase biaya tenaga kerja pada tahun 2014

\begin{tabular}{lccc}
\hline Bulan (1) & Biaya Tenaga Kerja (2) & Jumlah Hpp (3) & \% (2):(3) $\times \mathbf{1 0 0 \% )}$ \\
\hline Januari & 394.480 .000 & 6.394 .710 .386 & 06,17 \\
\hline Februari & 305.935 .000 & 5.441 .078 .848 & 05,62 \\
\hline Meret & 326.115 .000 & 5.477 .527 .495 & 05,95 \\
\hline April & 344.430 .000 & 6.747 .400 .881 & 05,10 \\
\hline Mei & 381.390 .000 & 6.939 .784 .639 & 05,49 \\
\hline Juni & 324.455 .000 & 5.879 .599 .183 & 05,51 \\
\hline Juli & 284.645 .000 & 4.804 .475 .329 & 05,92 \\
\hline Agustus & 324.455 .000 & 5.652 .613 .972 & 58,07
\end{tabular}

\begin{tabular}{lccc}
\hline Srptember & 364.500 .000 & 5.561 .610 .577 & 06,55 \\
\hline Oktober & 459.930 .000 & 9.482 .964 .553 & 04,85 \\
\hline November & 426.710 .000 & 7.326 .050 .611 & 05,82 \\
\hline Desember & 364.120 .000 & 6.653 .822 .780 & 05,47 \\
\hline Jumlah & 4.211 .165 .000 & 7.651 .751 .1254 & $\mathbf{1 4 , 5 0}$ \\
\hline
\end{tabular}

(Sumber: lampiran 3)

Dapat diketahui berapa persen besar biaya tenaga kerja terhadap harga pokok produksi pada perusahaan selama tahun 2014.Adapun besarnya persentase biaya tenaga kerja terhadap harga pokok produksi selama tahun 2014 dapat dijelaskan sebagai berikut. Pada Bulan Januari Tahun 2014 Biaya Tenaga Kerjamemberikan persentasenya terhadap Harga Pokok Produksi sebesar 06,17\% dari jumlah Harga pokok produksi bulan januariyaitu sebesar Rp. 6.394.710.386. Sementara pada bulan februari Biaya Tenaga Kerja memberikan persentasenya terhadap Harga Pokok Produksi sebesar 05,62\% dari jumlah harga pokok produksi sebesar Rp.5.441.078.848. 
Sedangkan untuk Biaya tenaga kerja terhadap Harga Pokok Produksi sebesar 05,95\%, dari jumlah harga pokok produksi sebesar Rp.5.477.527.495. Kemudian pada Bulan April biaya tenaga kerja memberikan persentasenya terhadap Harga Pokok Produksi 05,10\%, dari jumlah harga pokok produksi sebesar 6.747.400.881.

Selanjutnya pada Bulanbiaya tenaga kerja memberikan persentasenya terhadap Harga Pokok Produksi 05,49\%, dari jumlah harga pokok produksi sebesar Rp.6.939.784.639 Selanjutnya pada bulan Juni biaya tenaga kerja memberikan persentasenya terhadap Harga Pokok Produksi sebesar 05,51\% dari jumlah harga pokok produksi sebesar 5.879.599.183. Selanjutnya pada Bulan Juli biaya tenaga kerja memberikan persentasenya terhadap Harga Pokok Produksi sebesar 05,92\% dari jumlah harga pokok produksi sebesar 4.804.475.329. Selanjutnya pada Bulan Agustus biaya tenaga kerja persentasenya terhadap Harga Pokok Produksi sebesar 58,07\%, dari jumlah harga pokok produksi sebesar 5.652.613.972. Sementara pada Bulan September biaya tenaga kerja memberikan kontribusi sebesar 0,655\% terhadap Harga Pokok Produksi, dari jumlah harga pokok produksi sebesar Rp.5.561.610.577. Kemudian pada Bulan Oktober biaya tenaga kerja memberika persentasenya sebesar $\quad 04,85 \%$ terhadap Harga Pokok Produksi, dari jumlah harga pokok produksi sebesar Rp. 9.482.964.553. Kemudian Bulan November biaya tenaga kerjamemberikan persentasenya sebesar $05,82 \%$ terhadap harga pokok produksidari jumlah harga pokok produksi sebesar Rp.7.326.050.610. Sementara pada Bulan Desember biaya tenaga kerja memberikan persentasenya sebesar 05,47\% terhadap Harga Pokok Produksi, dari jumlah harga pokok produksi sebesar Rp.6.653.822.780

3) Perhitungan besarnya biaya overhead pabrik terhadap harga pokok produksi.

Dalam biaya overhead pabrik untuk perusahaan yang menggunakan metode harga pokok produksi, yaitu semua elemen biaya produksi selain biaya bahan baku, dan biaya tenaga kerja diman elemennya dapat digolongkan kedalam (1) biaya penyusutan, (2) biaya listrik dan air, (4) biaya asuransi pabrik, (5) biaya overhead pabrik lain-lain. Apabila perusahaan memiliki departemen pembantu didalam pabrik, semua biaya departemen pembantu dimasukka sebagai elemen biaya overhead pabrik.Biaya overhead pabrik dapat dipakai sebagai pengendalian biaya overhead dalam sebuah perusahaan.Biaya overhead pabrik tersebut diperoleh dengan terlebih dahulu melacak biaya - biaya overhead pabrik secara individual. 
Penjumlahan biaya overhead pabrik denagn biaya utama menghasilkan harga pokok produksi.Dalam perusahaan ini perhitungan biaya overhead pabrik merupakan perhitungan seluruh biaya- biaya penunjang yang dikeluarkan oleh perusahaan seperti biaya pengeluaran pembayaran listrik, biaya pembayaran air, kaleng, karton maupun biaya pembantu lainnya yang sudah dilakukan perhitungan sebelumnya yang sudah dimasukkan kedalam harga pokok produksi. Perhitungan persentase tersebut dapat dilakukan dengan menggunakan rusmus sebagai berikut.

Tabel 3. Persentase biaya overhead pabrik pada tahun 2014

Bulan (1) Biaya Overhead Pabrik Jumlah Hpp $\quad \%(2):(3) \times 10 \%)$

\begin{tabular}{llll}
\hline Januari & 3.489 .710 .991 & 6.394 .710 .386 & 54,57 \\
\hline Februari & 2.884 .679 .243 & 5.441 .078 .848 & 53,01 \\
\hline Meret & 2.832 .400 .864 & 5.477 .527 .495 & 51,70 \\
\hline April & 3.777 .410 .110 & 6.747 .400 .881 & 55,98 \\
\hline Mei & 3.815 .551 .210 & 6.939 .784 .639 & 54,98 \\
\hline Juni & 2.812 .300 .754 & 5.879 .599 .183 & 47,83 \\
\hline Juli & 2.484 .652 .345 & 4.804 .475 .329 & 51,71 \\
\hline Agustus & 2.875 .300 .160 & 5.652 .613 .972 & 50,86 \\
\hline Srptember & 2.822 .515 .235 & 5.561 .610 .577 & 50,74 \\
\hline Oktober & 4.815 .959 .922 & 9.482 .964 .553 & 50,78 \\
\hline November & 3.988 .233 .115 & 7.326 .050 .611 & 54,44 \\
\hline Desember & 3.598 .113 .253 & 6.653 .822 .780 & 54,07 \\
\hline Jumlah & 33.981 .426 .747 & 76.517 .511 .254 & $\mathbf{4 4 , 4 1}$
\end{tabular}

(Sumber: lampiran 3)

Dapat diketahui seberapa besar biaya overhead pabrik memberikan prosentasenya terhadap harga pokok produksi pada perusahaan selama tahun 2014. Adapun besarnya prosentase biaya overhead pabrik terhadap harga poko produksi selama tahun 2014 dapat dijelaskan sebagai berikut pada bulan Januari tahun 2014 prosentase biaya overhead terhadap harga pokok produksi $54,57 \%$ dari jumlah harga pokok produksi yaitu sebesar Rp.6.394.710.386 sementara pada bulan Februari biaya overhead pabrik memberikan prosentasenya 
terhadap harga pokok produksi sebesar 53,01\% dari jumlah harga pokok produksi Rp.5.441.078.848. Sedangkan untuk bulan Maret biaya overhead pabrik memberikan prosentasenya terhadap harga poko produksi sebesar Rp.5.477.527.495. kemudian pada bulan April biaya overhead pabrik memberikan prosentase terhadap harga pokok produksi sebesar 55,98\% dari jumlah harga poko produksi sebesar Rp.6.747.400.881. Selanjutnya pada bulan Juni biaya overhead pabrik memberikan prosentasnya sebesar $47,83 \%$ terhadap harga pokok produksi. Jumlah harga pokok produksi sebesar Rp.5.789.599.183. Selanjutnya pada bulan Juli biaya overhead pabrik memberikan prosentasenya sebesar $57,71 \%$ terhadap harga pokok produksi dari jumlah harga pokok produksi sebesar Rp.4.804.475.329. Kemudian pada bulan Agustus biaya overhead pabrik memberikan prosentasenya terhadap harga pokok produksi sebesar $50,86 \%$ dari jumlah harga pokok produksi sebesar Rp. 5.561.610.577. Sementara pada Bulan September biaya overhead pabrik memberikan persentasenya sebesar 50,74\% terhadap Harga Pokok Produksi dari jumlah harga pokok produksi Rp. 9.482.964.553. Kemudian pada bulan Oktober biaya overhead pabrik memberikan persentasenya sebesar 50,78\% terhadap Harga Poko Produksi dari jumlah harga pokok produksi sebesar Rp. 5.561.610.577.
Kemudian Bukan November biaya overhead pabrik memberikan persentasenya sebesar 54,44\% terhadap Harga Pokok Prodyuksi dari jumlah harga pokok produksi sebesar 7.326.050.611. Sementara pada Bulan Desemberbiaya overhead pabrik memberikan persentasenya sebesar 54,07\% terhadap Harga Pokok Produksi dari jumlah harga pokok produksi sebesar Rp. 6.653.822.780.

Dari perhitungan data diatas diketahui biaya overhead pabrik memberikan persentasenya yang besar terhadap harga pokok produksi, dan dengan melakukan perhitungan tersebut perusahaan dapat lebih jelas melihat peningkatan dan penurunan pada setiap periode seberapa besar persentase biaya overhead pabrik yang masuk terhadap harga pokok produksi tersebut.

(4) Persentase besar persentase jumlah rasio biaya bersama terhadap harga pokok produksi pada PT. Maju Tambak Sumurtahun 2014.

Biaya bersama adalah biaya yang dikeluarkan sejak saat mula mula bahan baku diolah sampai dengan saat berbagai macam produk dapat dipisahkan identitasnya. Bila dalam suatu proses dapat dihasilkan lebih dari satu produk maka produk tersebut dinamakan produk bersama. Pada perusahaan manufaktur diperusahan pengalengan ikan biaya 
yang dikeluarkan antara lain biaya bahan baku,biaya tenaga kerja, dan biaya overhead pabrik. Tujuan alokasi biaya bersama adalah untuk perhitungan biaya produk, yang digunakan untuk penilaian sediaan dan penentuan laba. Karakteristik biaya bersama adalah tidak dapat ditelusuri secara langsung dan jelas pada setiap jenis produk yang dihasilkan sehingga perlu dilakukan alokasi biaya bersama pada produk tersebut.

Sebelum melakukanpenghitungan untuk melihat rasio (persentase) biaya bersama maka perlu dilakukan penghitungan secara terpisah pada setiap biaya produksi. Setelah melakukan penghitungan tersebut maka penghitungan rasio (persentase) dapat dilakukan dengan menggunkan perhitungan sebagai berikut.

$\frac{\text { Jumlah biaya bersama }}{\text { jumlah nilai jual }} \times 100 \%=$

Tabel 4. Perhitungan rasio (persentase) biaya bersama terhadap harga pokok produksi

\begin{tabular}{|c|c|c|c|}
\hline \multirow{3}{*}{ Macam Biaya } & \multicolumn{2}{|c|}{ Jumlah Nilai } & \multirow{3}{*}{ Alokasi Biaya Bersama } \\
\hline & & & \\
\hline & $\mathrm{Rp}$ & $\%$ & \\
\hline Biaya Bahan Baku & 31.447 .790 .898 & 45 & 14.151 .505 .904 \\
\hline Biaya Tenaga Kerja & 4.211 .165 .000 & 60 & 4.211 .164 .999 \\
\hline \multicolumn{4}{|l|}{ Biaya Overhead } \\
\hline Pabrik & 33.981 .426 .747 & 48 & 33.981 .426 .699 \\
\hline & & 1.330434 & 52.344 .097 .603 \\
\hline Jumlah & 69.659 .955 .898 & & \\
\hline$\frac{659.955 .898}{344.097 .603} \times 100 \%=$ & $30434=13,30$ & & \\
\hline
\end{tabular}




\section{PEMBAHASAN}

Berdasarkan hasil penelitian mengenai persentase biaya bahan baku, biaya tenaga kerja, dan biaya overhead pabrik pada persahaan pengalengan ikan. PT. Maju Tambak Sumur dapat diketahui bahwa pada laporan harga pokok produksi tahun 2014, perusahaan belum mengetahui seberapa besar biaya-biaya yang di keluarkkan perusahaan memberikan persentasenya terhadap harga pokok produksi tersebut. Hal ini dikarenakan belum dilakukannya perhitungan secara terperinci oleh perusahaan. Hasil penelitian dengan menggunakan analisis tersebut mengenai seberapa besar persentasenya biaya bahan baku terhadap harga pokok produksi menunjukan bahwa biaya bahan baku memberikan persentasenya terhadap harga pokok produksi sebesar 53,07\%. Sedangkan biaya tenaga kerja memberikan persentase sebesar 70,57\%. Dan biaya overhead pabrik memberikan persentase terhadap harga pokok produksi sebesar 52,55 \%. Hasil perhitungan ini untuk melihat seberapa besar persentase dari biaya - biaya yang masuk kedalam harga pokok produksi, karena melalui laporan harga pokok produksi dapat terlihat besarnya persentase dari masingmasing biaya yang di keluarkan.

Oleh karena itu dalam perusahaan manufaktur, biaya dapat dikelompokkan menjadi tiga kelompok yaitu,
1) Biaya Produksi merupakan biayabiaya yang terjadi untuk mengolah bahan baku menjadi produk jadi yang siap untk dijual. Menurut obyek pengeluarannya, biaya produksi dapat dibagi menjadi: biaya bahan baku, biaya tenaga kerja, dan biaya overhead pabrik.

2) Biaya Pemasaran merupakan biaya-biaya yang terjadi untuk melaksanakan kegiatan pemasaran produk.

3) Biaya Administrasi dan Umum merupakan biaya-biaya yang terjadi untuk mengkoordinasi kegiatan produksi dan pemasaran produk.

Secara keseluruhan berdasarkan hasil penelitian dari ketiga faktor biaya produksi pada PT. Maju Tambak Sumur perhitungan harga pokok produksi sangat bermanfaat untuk mengetahui besarnya persentase dari masingmasing biaya produksi tersebut. Hal ini sesuai dengan pernyataan yang diungkapkan". Menurut Ahmad Firdaus (2009:42) mengatakan “ harga pokok produksi (manufacturing cost) adalah biayabiaya yang secara langsung berhubungan dengan produksi yaitu biaya bahan langsung, dan biaya tenaga kerja ".Penelitian ini sesuai dengan hasil penelitian Muhammad Hafizh Aufaro (2011) yang menyatakan laporan yang sangat akurat tentang biaya yang 
dikeluarkan selama proses produksi dilaksanakan oleh perusahaan untuk memperoleh informasi mengenai biaya produksi ini dibutuhkan pengelolaan data sesuai dengan teori serta prinsip akuntansi, khususnya akuntansi biaya. Akuntansi biaya dalam perusahaan bertujuan untuk menyajikan informasi harga pokok produksi per satuan produk jadi. Akuntansi biaya ini digunakan untuk menghitung biaya yang dikeluarkan dari setiap proses yang dilakukan mengolah bahan setengah jadi atau pun produk jadi. Untuk memproduksi barang jadi itu sendiri dibutuhkan biaya yang cukup besar dan komponen biaya yang mendapat perhatian cukup serius adalah biaya produksi. Biaya produksi ini terdiri dari biaya bahan baku, biaya tenaga kerja langsung dan biaya overhead pabrik. Informasi biaya produksidapat digunakan manajemen untuk menetapkan harga pokok produksi yang nantinya akan menjadi alat bagi manajemen dalam opreasional perusahan harga pokok produksi merupakan salah satu faktor yang menentukan harga jual produk. Harga pokok produk yang tinggi akan menghasilkan harga jual yang tinggi pula. Harga pokok produk yang tinggi akan mengurangi persentase laba yang diinginkan.

\section{SIMPULAN}

Berdasarkan hasil simpulan dan pembahasan, maka dapat disimpulkan sebagai berikut.
1) Pada PT. Maju Tambak Sumur Besar biaya bahan baku memberikan persentasenya terhadap harga pokok produksi selama tahun 2014 sebesar 41,09\%.

2) Pada PT.Maju Tambak Sumur biaya tenaga

kerja memberikan persentasenya terhadap harga pokok produksi selama tahun 2014 terlihat persentasenya sebesar $14,50 \%$.

3) Pada PT. Maju Tambak Sumur biaya overhead pabrik memberikan persentase terhadap harga pokok produksi selama tahun 2014 sebesar 44,41\%.

4) Pada PT.Maju Tambak Sumur rasio (persentase) biaya bersama terhadap harga pokok produksi selama tahun 2014 maka dapat diketahui besarnya rasio biaya bersama sebesar $13,30 \%$

\section{SARAN}

Berdasarkan simpulan diatas ,maka dapat dikemukakan saran sebagai berikut.

1) Bagi PT. Maju Tambak Sumur

Perhitungan biaya - biaya yang

di keluarkan pada setiap proses produksi sebaiknya selalu dilakukan perhitungan secara terperinci baik dari biaya bahan baku, biaya tenaga kerja, maupun biaya Overhead pabrik. Melalui perhitungan yang terperinci dalam laporan Harga Pokok Produksi tersebuT PT. Maju Tambak Sumur dapat mengetahui 
seberapa besar persentase masingmasing biaya produksi yang di keluarkan dalam periode tertentu.

2) Bagi Akademik

Bagi peneliti lain yang bermaksud melakukan penelitian di bidang Akuntansi Biaya atau khususnya tentang Harga Pokok Produksi diharapkan mampu menganalisis pada subjek lain pada perusahaan manufaktur bidang pangan,dan diharapkan untuk melakukan penelitian lebih lanjut dan mendalam terkain dengan biayabiaya produksi terhadap Harga Pokok Produksi sehingga mampu membandingkan perbedaan hal - hal lain untuk melihat besarnya persentase terhadap yang terdapat pada Harga Pokok Produksi selain dari biaya - biaya produksi tersebut.

\section{DAFTAR PUSTAKA}

Carter dan Usry. 2002. Akuntansi Biaya. Edisi ketiga belas.

Buku Satu. Jakarta:

Salemba Empat

Carter, William. 2009. Akuntansi Biaya. Buku Satu. Edisi Empat Belas. Jakarta: Salemba Empat Daljono. 2011. Akuntansi Biaya, PenentuanHarga Pokok dan Pengendalian, Edisi Ketiga. Cetakan Kedua.

Semarang: BP Undip.

Firdaus Ahmad Dunia dan Wasilah. 2009. Akuntansi Biaya. Edisi 2. Jakarta: Salemba Empat.
Hansen \& Mowen. 2001. Manajemen Biaya, Edisi bahasa Indonesia, Buku Dua, Edisi Pertama. Jakarta: Salemba Empat.

2005.

Management Accounting. Buku 2 Edisi ke 7. Salemba Empat. Jakarta.

Akuntansi Managerial Buku 1.

Edisi 8. Terjemahan oleh Denny Arnos Kwary. Jakarta: Salemba Empat.

Kholmi dan Yuningsih. 2009. Akuntansi Biaya Edisi Revisi. Malang: UMM Press.

Mulyadi.2005. Akuntansi Biaya edisi ke-6. Yogyakarta: STIE YKPN --------. 2009. Auditing Edisi 6

Buku 1. Jakarta: Salemba Empat

Munandar. M.2000. Budgeting. Cetakan ke-1.Yogyakarta: BPFE.

Mursyidi. 2008. Akuntansi

Keuangan Menengah Berbasis PSAK. Bandung: Refika Aditama

Sudiyono.Anas.2009. Pengantar Statistik pendidikan.Ed 1-20, Jakarta: Rajawali per 